\title{
Analysis on the Function of Vocational Education to Accelerate the New Rural Construction
}

\author{
Yanling Teng ${ }^{1, \mathrm{a}}$ and Fengwu Zhu ${ }^{2, \mathrm{~b}^{*}}$ \\ ${ }^{1,2}$ Xincheng Street 2888, Jilin Agricultural University, Changchun, Jilin Province 130118, PR China \\ 447568174@qq.com \\ * The Corresponding author
}

Keywords: Vocational education; New rural construction; Function analysis

\begin{abstract}
The new rural construction in 2005 in the party in the fifth Plenary Session of the 16th CPC Central Committee through the "outline of the plan for the year 11th Five-Year," a resolution in the new countryside on the road to realize the education plays an important role. In the 2017 vocational education and continuing education work points, clearly put forward to increase rural and poor areas of vocational education support. This article mainly analyzes the current situation of the development of vocational education in rural areas from the perspective of vocational education, including the backwardness of vocational education, the irrationality of professional curriculum facilities and the uneven distribution of teaching resources. At the same time from the combination of regional economic development, to create a diversified way of running schools and to speed up the construction of agriculture-related professional, new rural construction and training of specialized personnel and other aspects of specific reform measures, Finally, from the rural vocational education to promote the improvement of the quality of rural labor, rural vocational education to promote the process of rural urban integration and rural vocational education to promote agricultural science and technology progress, speed up industrial restructuring and other aspects of the important role of rural vocational education analysis.
\end{abstract}

\section{Introduction}

China is a large population, but also a large agricultural country, since ancient times, the country's support for the development of agriculture is quite large, in the Central No. 1 document repeatedly introduced support agriculture, rural areas, farmers "three rural" policy. In this, farmers play a key role, especially in the new rural construction; the farmers are the main force of construction. Therefore, in some ways, the quality of farmers has become a new rural construction constraint. Therefore, we must speed up the development of vocational education in rural areas, improve the overall quality of farmers, and cultivate new scientific farmers, thus speeding up the construction of new socialist countryside.

\section{The Status of Vocational Education in Rural Development}

The Concept of Vocational Education is Backward. Compared with the city's vocational education, most of the rural vocational education is far behind, not only in the school funds, teachers, teaching equipment and other teaching resources behind, including the creation of professional curriculum system is difficult to keep up with the times and market demand, Students empty theoretical knowledge, and the lack of practical application of knowledge, is not conducive to the development of students. In addition, the occupation education concept has not been fully understood, many parents in rural areas are "heavy general education, light vocational education, in their view that only learn not good talent will go to college occupation education, from the heart to give conflict to the occupation education, occupation education enrollment caused difficulties.

Irrational Setting of Professional Courses. In many rural vocational colleges, courses are mostly modeled on ordinary institutions, such as financial management, tourism management, marketing and other theoretical courses. We do not have professional courses based on agriculture 
such as garden, planting, fruit and vegetable and other traditional agriculture and farm products transportation, storage and e-commerce of agricultural characteristic product based on local characteristics. It can be seen that the irrational focus of the curriculum is irrational in the structure of the theoretical and practical courses, and the practice course fails to be trimmed according to the change of market demand in time.

Uneven Distribution of Educational Resources. At present, China's rural vocational education is facing insufficient funds, weak teachers, resource allocation imbalance and other issues. First of all, the lack of funds is mainly reflected in two aspects, one is the government capital investment is not enough, the second is the enterprise investment in vocational education less. Secondly, the teacher strength is weak because the rural vocational school teachers theoretical knowledge and practical knowledge is poor, which means that most teachers are not professional counterparts. In addition, the teacher structure is unreasonable, one is irrational level of education, most teachers are specialist, undergraduate and graduate education teachers less. Second, the age level is unreasonable, rural vocational school teachers in the age structure of the proportion of young teachers too little. Third, the number of "double teacher" teachers is seriously inadequate. Finally, the allocation of teaching resources imbalance. Mainly including rural vocational colleges teaching facilities are more backward, the experimental equipment is not perfect, the lack of modern teaching facilities; also includes no supporting practice practice base and platform.

\section{To Speed Up Rural Vocational Education Measures}

For the rural vocational education is to serve the rural areas, farmers and agriculture, including agriculture, including agriculture, forestry, animal husbandry, vice, fishing, water conservancy and other aspects, to speed up the rural vocational education to speed up the construction of new socialist countryside, promote the process of urbanization accelerate plays an important role.

Combined with the Regional Economic Development, to Create a Diversified Way of Running A School. The development of rural vocational education should be based on the characteristics of economic development in the region, the use of local characteristics of agricultural enterprises, factories, funds and venues to improve the school infrastructure and rural students to solve the problem of practice base, more importantly, which can take "government main, business participation" in the form of diversified school to carry out the form. In the aspect of running a school, the flexible credit system is adopted to encourage the students to teach and study in the countryside, and to complete their studies by means of work study alternation and post-practice.

To Speed Up the Construction of Agriculture-related Professional, for the New Rural Construction and Training of Specialized Personnel. Rural vocational education should vigorously carry out the construction of agriculture-related agriculture. With the deepening of the importance of water conservancy projects in recent years, rural vocational education should set up a number of water conservancy and water conservancy institutions and give appropriate help in the policy. At the same time, with the food safety more and more attention, run food professional institutions and food professional become an imminent thing. In accordance with the ecological civilization construction and industrial development needs, service ten ecological barrier and ten leading industry construction, run a number of forestry vocational schools and forestry professional, vigorously carry out the vocational training for farmers ${ }^{[1]}$.

Optimize the Professional Curriculum, Build A Sound Curriculum System. First of all, according to the local economic development and industrial structure, social occupation and labor market demand and other circumstances to investigate, according to the relevant categories of talent, structure and quantity and other data requirements, institutions should be timely and accurate adjustment of professional settings, set up in line with local agricultural characteristics Of the vocational education curriculum system, to create a number of highly specialized professional curriculum system. Secondly, according to the forefront of domestic and foreign vocational education policies and news, learn from advanced foreign curriculum model, combined with the characteristics of the region, by virtue of "Western learning with reference module" principle, rural vocational colleges to improve students' comprehensive quality and professional ability as the core, 
through the practice of training to cultivate students' comprehensive vocational skills. Finally, through the introduction of foreign vocational schools flexible management system of school management methods, rural vocational institutions can also learn from the elastic academic system to change the teaching system. Elastic system is characterized by the cultivation of students without a fixed time and age restrictions, according to the actual situation of each student and need to teach students, to develop a specific credit system. This kind of flexible academic system can greatly stimulate students' interest in learning, can bring new vitality to the school, and effectively promote the cultivation of talents.

To Strengthen the Construction of Teachers, Increase Capital Investment, Improve the Treatment of Teachers. The development of rural vocational education is inseparable from the strength of teachers, to this end, in order to attract the majority of teachers under the grassroots to rural teaching, the government in addition to improving the rural vocational education institutions of infrastructure construction, but also gradually improve the employment system, Actively promote the distribution of wage income. At the same time, to provide teachers with a variety of training opportunities to encourage vocational education teachers to carry out "teaching competition" and other activities, so as to improve the quality of teachers, and constantly strengthen the "double teacher" teacher training.

\section{The Role of Rural Vocational Education in the Construction of New Socialist Countryside}

Rural Vocational Education to Promote the Improvement of Rural Labor Quality. Although with the nine-year compulsory education and the popularity of higher education continues to improve, but the rural labor force is still low quality, lack of scientific and cultural knowledge and other issues. Vigorously develop rural vocational education can be targeted to improve the scientific and cultural quality of rural areas, so as to adapt to the development of non-agricultural industries, and vigorously promote the adjustment of agricultural industry structure, so as to provide new socialist countryside construction personnel.

Rural Vocational Education to Accelerate the Process of Rural Urban Integration. Rural urbanization construction is an effective measure to divert rural surplus labor force from agriculture, and its promotion cannot be separated from the support of vocational education ${ }^{[2]}$. However, the key to the new rural urbanization in China is to promote the urbanization of the rural population. The important measure is the transfer of the rural surplus labor force to the cities. At this time, vocational education has cultivated a large number of talents to meet the agricultural specialty so as to facilitate the transformation of the rural economic structure. Fundamentally promote the development of rural socio-economic and industrial structure of the adjustment, and ultimately adapt to the adjustment of rural social and economic structure and urbanization requirements.

Rural Vocational Education Promotes Agricultural Science and Technology Progress and Accelerates Industrial Structure Adjustment. Accelerate the development of rural vocational education, rural science can improve the scientific and technological progress, but also for the rural industrial structure adjustment to cultivate a large number of scientific and technological personnel. Therefore, the rural industrialization can gradually to the development of science and technology-intensive industries, and promotes the continuous popularization of rural science and technology. Thus promoting the socialist new rural construction process is accelerating.

\section{Conclusion}

To speed up the development of rural vocational education, can be strong for the construction of new socialist countryside to cultivate scientific and professional talents, so as to promote the adjustment of rural industrial structure, and ultimately China's rural construction into economic prosperity, facilities, beautiful environment, civilized and harmonious new socialist countryside. 


\section{References}

[1] Ministry of Education and other nine departments on accelerating the development of rural areas for the views of vocational education[2011] No. 13

[2] Liang Xiulan; Li Fangtao. On the relationship between the construction of new socialist countryside and rural vocational education [J]. Vocational Education Research, 2015 (2): 8-10. 